\title{
3 次元コンピュータグラフィックスにおける アンティエイリアシングの高速化アルゴリズム ACCELERATED ALGORITHM OF ANTIALIASING AT 3 DIMENSIONAL COMPUTER GRAPHICS
}

\author{
笠原信一* \\ Shinichi KASAHARA
}

\begin{abstract}
Aliasing phenomenon in Computer Graphics images and animations is serious problem to lose quality. Techniques to solve the problem, namely antialiasing technique, have been researched and developed, but these usual techniques have weak point to consume much calculation time. This paper proposes a new antialiasing algorism that keeps image quality and speeds calculation up. Applying different antialiasing method to each step at rendering process, namely finding visible object, shadow casting, mapping, and reflecting, is main strategy of the new algorism proposed here. Appropriate different method for each step can optimizes image quality and calculation time.
\end{abstract}

Keywords : 3 Dimensional Computer Graphics, Aliasing, Antialiasing, Acceleration 3 次元コンピュータグラフィックス, エイリアシング, アンティエイリアシング、高速化

\section{1.はじめに}

コンピュータグラフィックス (CG) の画像は、ピクセルと呼ばれ る格子状に並んだ微小の画素の集まりで構成されており、離散化さ れたデジタル画像である。従って、アナログの三次元空間をデジタ ル化する過程で、情報が欠落し画像が劣化することがある。この現 象をエイリアシング(aliasing)と呼んでいる。具体的には、CG 画像 の中でエッジのギザギザ（図 1) や遠方での不正な縞模様（図 2） といった現象となって現れる。また動画では、そのエッジのギザギ ザや縞模様が摇れ動くことによって、画面のちらつきを引き起こす。

この問題を解決する技術を総称してアンティエイリアシング (antialiasing) ${ }^{1), 2)}$ と呼んで扔り、CG の画像品質を向上させる上で 不可欠の技術である。これまでに様々なアンティエイリアシング手 法が開発され画質の改善が図られてきたが、これらの手法は一方で 計算負荷の増大という問題を招いている。コンピュータの処理能力 は飛躍的に進歩しているが、それに比例して制作される画像も複雑 化高度化しており、現在でも計算時間は $\mathrm{CG}$ 制作のネックになって いる。特に建築分野の CG は、ごく限られた対象者へのプレゼンテ ーション手段として制作されることが多いため、他分野（工業製品 業界、コマーシャル業界、映画業界など）のCGと比べて、より短 期間に低コストで制作する需要が高いが、建築分野の CG 制作現場 では、例えば 3 分程度のアニメーション作成の計算に数日閒という
膨大な計算時間をかけるのは珍しくない。建築分野における CG 利 用推進のためには、画像の品質と共に計算時間が重要な要素である。 本研究は、この問題を解決するために、高品質の CG を作成するソ

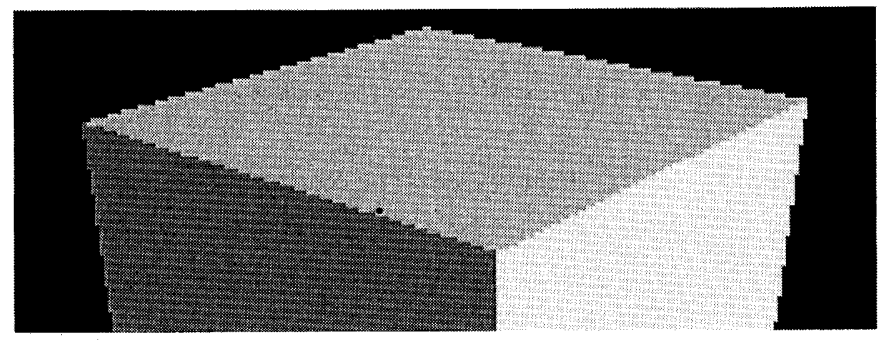

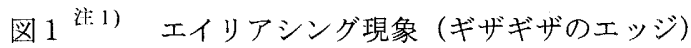

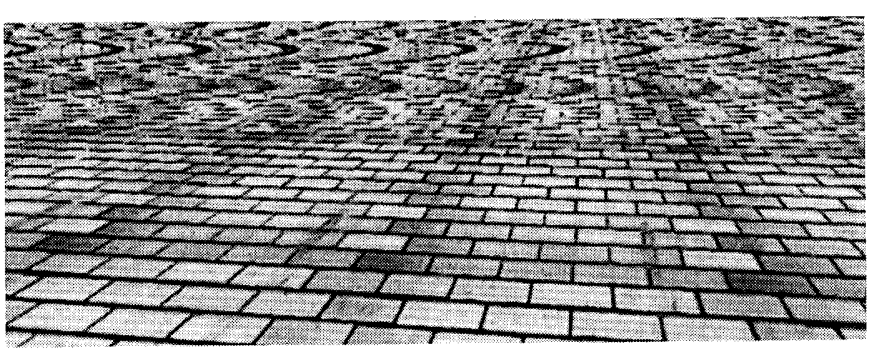

図 2 エイリアシング現象（遠力での不正な縞模様）

*鹿島建設㑣 ITソリューション部 担当部長・修士(芸術工学) Senior Manager, IT Solutions Department, Kajima Corporation, M. Design 
フトウエアのアンティエイリアシング処理を高速化する新アルゴリ ズムを開発する事を目的としている。

本稿で提案する新アルゴリズムは、アンティエイリアシング処理 を画像全体に一律に行うのではなく、「物体処理、光源処理、材質処 理といったエイリアシングの発生過程に注目し、各要因ごとにエイ リアシングの発生する箇所を抽出して、必要な部分のみにアンティ エイリアシング処理を行う」ことによって高速化するという点に新 規性がある。

\section{2. エイリアシングの甡生原因}

エイリアシングの発生は、連続的な変化（アナログ）をサンプリ ングで離散（デジタル）化することによる情報欠落が原因である。 1 ピクセルの幅よりも細かく情報が変化する部分では、ピクセル単 位でその変化を表現しきれず、情報が間引かれる結果として、画質 の劣化が生じる。

図 3 にエッジのギザギザの発生原因を示す。左図の原画像をデジ タル画像で表現する事を考える。画像領域を格子状の細かいピクセ ルに分割し、各ピクセル中央のサンプル点での色を求め、その色を ピクセルの色として代表させると、結果は右図のようにエッジが階 段状に表現される。

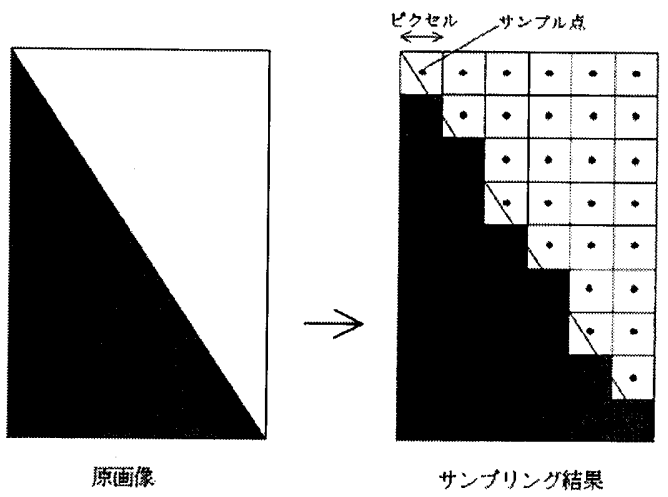

図 3 エッジのギザギザの原因

\section{3. 既往のアンティエイリアシング技術}

CG 画像のエイリアシングの問題を改善する技術はこれまで多く の研究があり、国際コンピュータ学会 ACM のグラフィックス部門 の学術論文誌である「Computer Graphics」や「ACM Transactions on Graphics」などを中心に発表されている。それらの研究は解析 的アプローチと離散化アプローチに大別される。

解析的アプローチは、画像の中でエイリアシングの発生する要因 に対して、図形処理的に予めエイリアシングの発生する籄所を解析 し、その简所にフィルタをかけてエイリアシングを消去しようとす る試みである。このアプローチは、高速に処理できる長所があるが、 物体のエッジ 3), 4),5),6),7),8),9),10) や表面模様 ${ }^{11), 12), 13), 14 ） と い ~}$ った特定のエイリアシング要因を改善するもので、それ以外の要因 （影や反射など）を含んだ複雑な画像には対応できず、適用範囲が 限定的である。

一方の離散化アプローチは、1 ピクセル内をさらに細かく分割し てサンプリングすることによってピクセル内に埋もれている情報を 抽出しエイリアシングを消去しようとする試みである。このアプロ
一チは、計算時間の増大を招くが、エイリアシング発生要因に関知 しないので任意の画像に適用できる汎用性がある。また、解析的な 複雑な処理によらずサンプル数を増やすだけでありアルゴリズムが 単純であるという長所もある。サンプリング方法には、均等サンプ

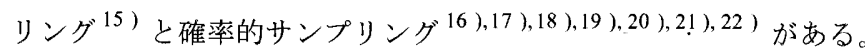
本研究は、CG 画像全般に汎用的に適用できる高速化手法の実現 をめざしているため、解析的アプローチではなく離散化アプローチ を採用している。

なお、アンティエイリアシング技術には、これらのソフト的な方 法以外に、ハードウエアによって处理する技術 23 ), 24),25),26) もあ る。ハードウエアによる手法はゲームのようなリアルタイム CG の ための技術であり、本研究で対象としているソフトウエアによる高 品質 CG の制作のための技術とは目的やアプローチが異なる。

以下に、本研究で採用している離散化アプローチの既往技術の概 要を示す。

\section{1 均等スーパーサンプリング法}

エイリアシングの発生は、サンプル数の不十分さが原因であるの で、サンプル数を増やすことによってエイリアシングが改善される。 図 3 では、各ピクセルに対してサンプルは1点であるが、これに対 して、ピクセルをさらに格子状のサブピクセルに分割し、サブピク セルごとにサンプル点をとり、それらの点での值の平均值をピクセ ルの值とする手法が均等スーパーサンプリング法 ${ }^{15)}$ である。

図 4 に均等スーパーサンプリングの様子を示す。図 4 左図は、図 3 右図の左上端の 1 ピクセルを拡大したものである。1 ピクセルが 36 のサブピクセルに分割されている。この手法では、複数のサンプ ル点の色の平均值をピクセルの色とするので、図 4 右図のように各 ピクセルは色の境界部分で中間の色を持つようになる。図 3 右図で ピクセルの色が白对黒のいずれかであるのと比べて、色が滑らか に変化している。

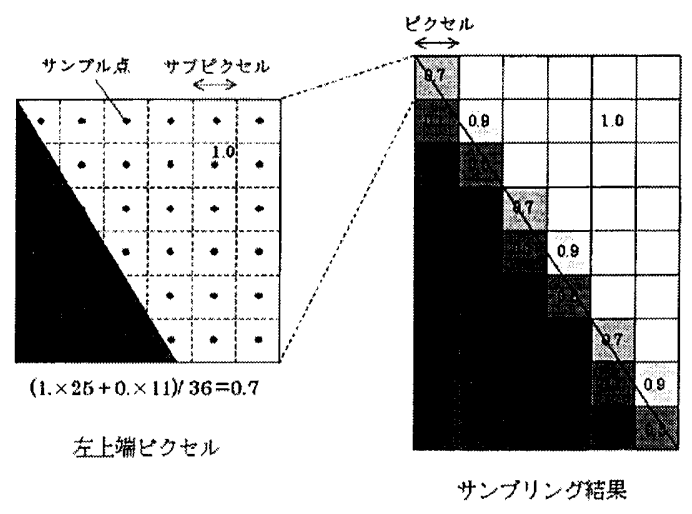

図 4 均等スーパーサンプリングによるエッジの平滑化

図 5 にスーパーサンプリング法による CG 画像作成处理全体の流 れを示す。左図がメインルーチンで、右図がレイトレーシング法 ${ }^{28)}$ により影、反射、表面模様などを考慮してサブピクセルの色を計算 するルーチンである（本稿はレイトレーシング法が論点ではないの で、右図は基本的な流れのみを簡略的に示している)。この右図の処 理を本稿では「色計算」ルーチンと呼ぶ。

(a)は画像の格子状のピクセルのループで、点線部分がスーパーサ 
ンプリング処理である。各ピクセルをさらに分割したサブピクセル ごとに(b)、「色計算」ルーチンを実行して色を求め(c)、各サブピク

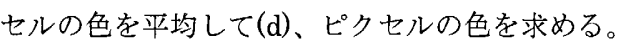
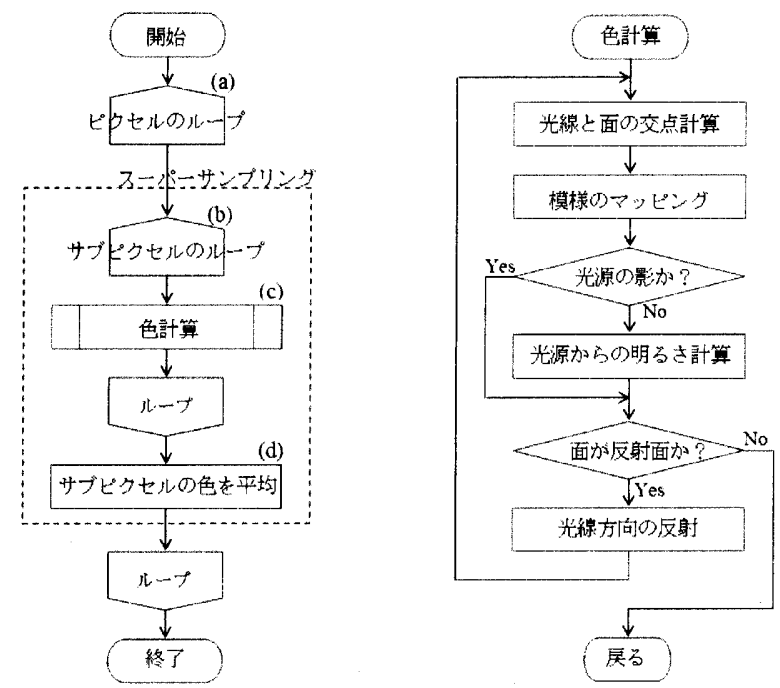

図 5 スーパーサンプリングによる画像作成の流れ図

\section{2 確率的スーパーサンプリング法}

均等スーパーサンプリング法は、サン プル点が格子状に規則的に並んでいるが、 規則的な間隔のサンプリングでは、いく らサンプルを多くとってもエイリアシン グ発生を完全に解決することはできない。 そこで、スーパーサンプリング時に、図 4 左図のようなサブピクセル中央点での サンプリングではなく、図6のように乱

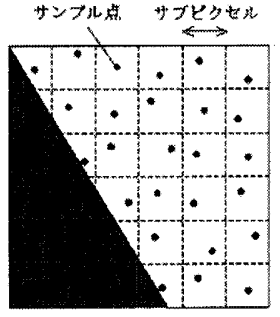

図 6
数によってサンプル点の位置を乱して不規則にする方法が、確率的 スーパーサンプリング法 ${ }^{16}$ ),17),18) である。図2のような不正な縞 模様は、模様の周期性とサンプリングの周期性の干渉が原因である ので、サンプリングの周期性をくずせば縞の発生を解消できる。

この時に、サンプル数を固定するのでなく、サンプル数を次第に 増やしていきながら值の収束状況を調べ、収束したと判断した時点 でサンプリングを打ち切る漸進確率サンプリング法 ${ }^{19}$ ), 20 ), 21 ),22 ) も考案されている。

\section{3 スーパーサンプリング法の杫算時間の间題}

既往のスーパーサンプリング法の問題は計算負荷の増大である。 サブピクセルの数を増やすほど画質は向上するが、それに比例して 計算時間も増加する。例えば、 $4 \times 4$ のサブピクセルで計算すると、 スーパーサンプリングしない場合に比べて 16 倍の計算時間がかか る。効率的な CG 制作のためには、アンティエイリアシング処理を 高速化する方法が重要である。

確率的サンプリングは均等サンプリングよりもさらに計算時間が かかる。レンダリングの高速化手法として、スキャンライン法 ${ }^{27)}$ と レイトレーシング法 ${ }^{28)}$ の統合技術 ${ }^{\text {注 }}{ }^{3)}$ があるが、確率的サンプリ ングを抗こうと、この統合技術が使えなくなる注 4) からである。 確率的サンプリングは、ハリウッドの CG 映画制作のように、計算
時間はいとわず究極の品質を求める場合には適しているが、建築分 野での CG では計算時間の効率も重要な要素であり、確率的サンフ リングを利用することは現実的でない。

\section{4.アンティエイリアシング离速化の新アルゴリズム}

本研究は、建築分野の CG の制作を前提にしているので、計算時 間に不利な確率的サンプリング法を採用せず、均等スーパーサンプ リング法を拡張してアンティエイリアシングを高速処理する新アル ゴリズムを提案する。

\section{1 新アルゴリスムの羊眼点}

画像の中でエイリアシングが発生するのは、色の急激な変化箩所 であるが、図1を見ても分かるように、画像の大半の部分は色の急 激な変化はなく、この部分にスーパーサンプリングを行っても計算 時間がかかるだけで画質には影響しない。そこで、「エイリアシング の発生するエッジを抽出し、そのエッジ籄所にだけスーパーサンプ リングを行う事によって画質を低下させずに高速化する」のが新ア ルゴリズムの第一の着眼点である。

画像の各ピクセルの色は、影、材質模様、反射像といった様々な 成分の重なりで構成されており、同じピクセルでも成分ごとにアン ティエイリアシング処理の必要性は異なる。例えば、模様がマッピ ングされた面に影が生じている場合、影内部のピクセルでは、模様 成分にはアンティエイリアシングが必要でも、影成分には必要ない。 そこで、「エイリアシングを一律に捉えるのではなく、その発生要因 に注目し、同じピクセルの中でも必要な成分にだけスーパーサンプ リングを行う」のが、新アルゴリズムのもう一つの着眼点である。

つまり、エイリアシング発生の「場所」と「成分」を特定し、必 要な部分だけにピンポイントでスーパーサンプリングする点に高速 化の独創性がある。以下に新アルゴリズムの流れを示す。

\section{2 物体エッジのアンティエイリアシング}

まず、画像の中で物体のエッジ部分を抽出して、物体エッジのア ンティエイリアシングを㧍こなう。本研究では、物体エッジの抽出 方法として、サブピクセルの面番号（サブピクセルでの可視面の識 別番号）を使用する方法を考案した。各サブピクセルの面番号は、 そのレンダリングの前処理としてスキャンライン法によって高速に 求めることができる。この面番号を利用し、「ピクセル内のサブピク セルの面番号が同一でない場合にのみスーパーサンプリングを行 う」ようにする。これにより物体エッジの存在しないピクセルのス ーパーサンプリングが省略され処理が高速化する。図 7 にその様子

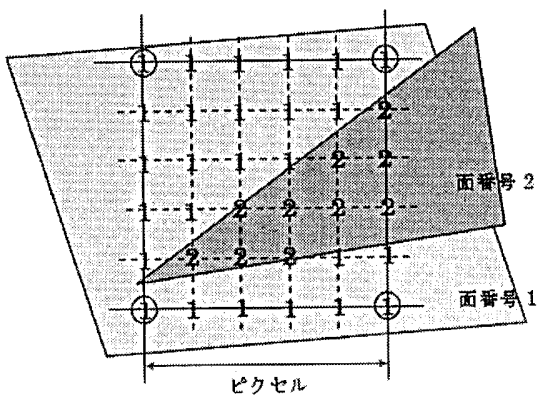

図 7 物体エッジの判定 
を示す。このピクセルでは、面番号 1 のサブピクセルと面番号 2 の サブピクセルが混在しているので、このピクセル内に物体のエッジ が存在すると判定しスーパーサンプリングを行う。

なお、透過物体の場合は、一つのサブピクセルに複数の面番号が 存在するので、サブピクセルごとに透過で見えるす心゙ての面番号を 保存して判定要素として使う必要がある。

図 $8(640 \times 400$ ピクセル、 $4 \times 4$ サブピクセル) の計算時間は、 均等スーパーサンプリング法では 24 秒注 2 ) であったが、新アルゴ リズムでは 4 秒注 2) で、6.0 倍の高速化であった。両手法で画質の 違いはない。図 9 は、図 8 の計算でスーパーサンプリングされたピ クセルを黒で表示したものである。この図から、物体のエッジが適 切に抽出されていること、スーパーサンプリングされたピクセルが 画像全体のごく一部であることがわかる。これが、新アルゴリズム によって画質を劣化させずに高速化が実現する理由である。

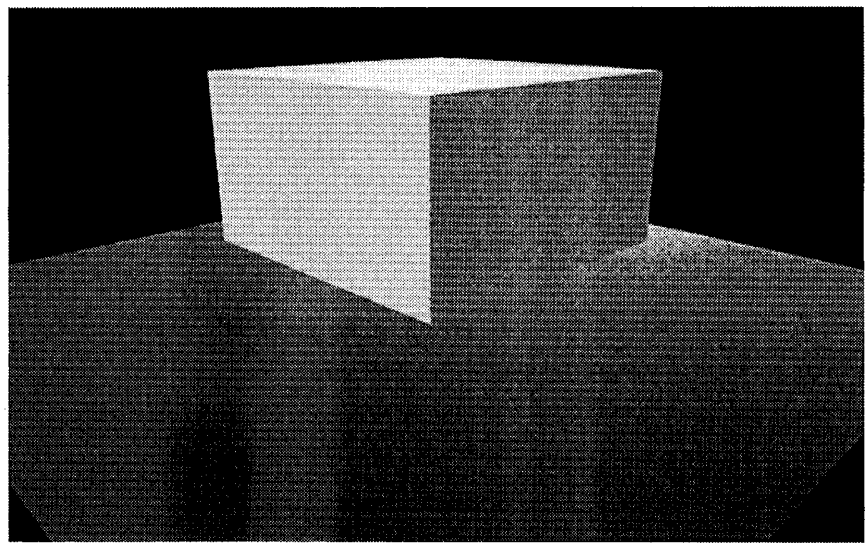

図 8 物体エッジのアンティエイリアシング

上記のアルゴリズムは、さ らに改良することができる。 モデルによっては、一つの面 が三角形に分割されている場 合や、地形のように曲面が細 かい面の集まりで表現されて いる場合がある。このような

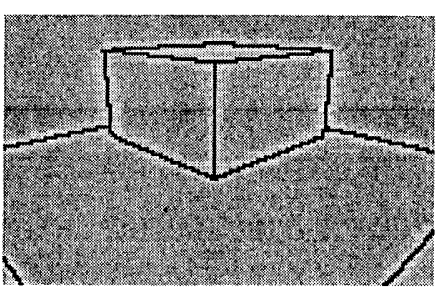

図 9
モデルでは、面のエッジは見えない（又ははっきりとは見えない） ので、この面どおしは擬似同一面とみなして、スーパーサンプリン グする箇所をさらに絞り込むことができる。そこで、「同一面番号で なくても、同じ材質で同じあるいは近い向きの面は、同一面番号で ある」とみなす。二つの面の向きが近いかどうかの判定は、両面の 垂直ベクトルのなす角度によっておこなうことができる。

\section{3 影のエッジのアンティエイリアシング}

上記の判定法は、物体のエッジのエイリアシングのみを解消する 方法であり、この方法を使って作成した画像は、物体のエッジは平 滑化されるが、影のエッジはギザギザのままになる（図 10）。同一 面であれば影の有無に関わらずスーパーサンプリングを省略するた めである。そこで、影のエッジを抽出してスーパーサンプリングす る新たな方法が必要となる。

新アルゴリズムでは、影のエッジ部分を抽出する方法として、ピ
クセルごとに影の重複する回数を記憶しておき、隣接の四つのピク セルで影の重複回数が異なれば影のエッジであるとみなし、このピ クセルをスーパーサンプリングする」ようにした（図 11）。

図 11 を $640 \times 400$ ピクセル（サブピクセル $4 \times 4 ）$ のサイズで計 算すると、均等スーパーサンプリング法では 41 秒 新アルゴリズムでは 6 秒注 2) で、6.8 倍の高速化であった。両手法 で画質の違いはない。均等スーパーサンプリング法では影計算によ って計算時間が 17 秒増加（図 8 の計算からの増加量）しているが、 新アルゴリズムでは 2 秒しか増加していない。図 12 は、図 11 の計 算でスーパーサンプリングされたピクセルを黒で表示したものであ るが、図 12 と図 9 を比べて黒の部分があまり増加していないこと が、影を計算しても計算時間があまり増加しない理由である。

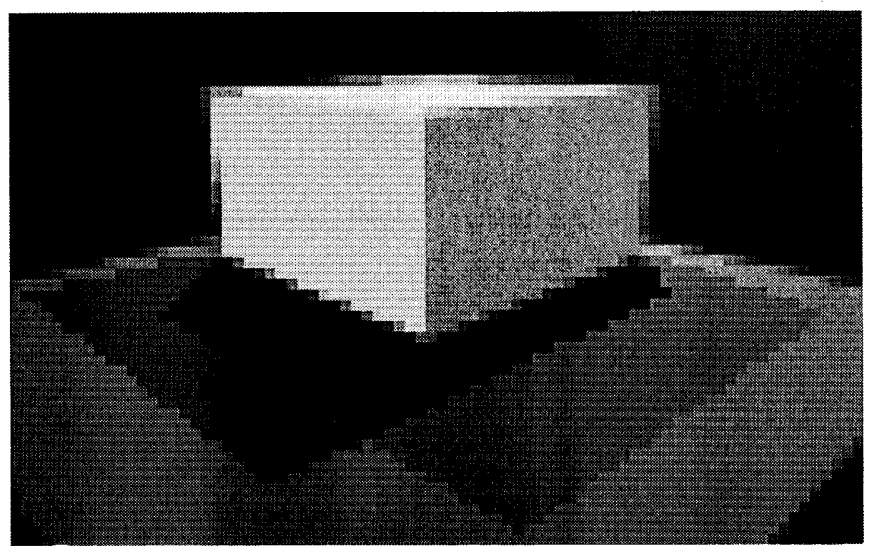

図 10 注 1) 平滑な物体エッジとギザギザの影エッジ

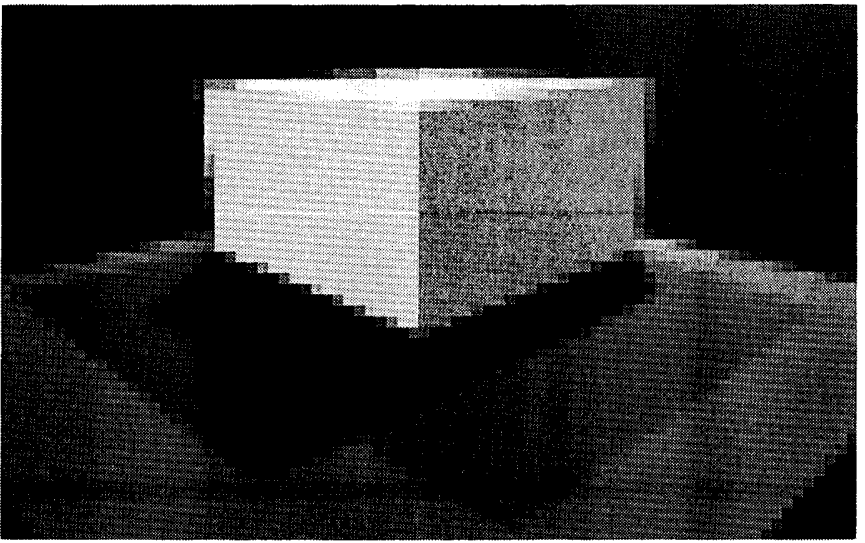

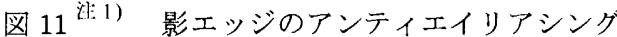

この影エッジ判定のアルゴ リズムは、通常の場合は問題 ないが、隣接する四点のピク セルの情報で判定しているた め、影の幅が 1 ピクセル以下 のような非常に細かい影は識 別できないという限界がある。

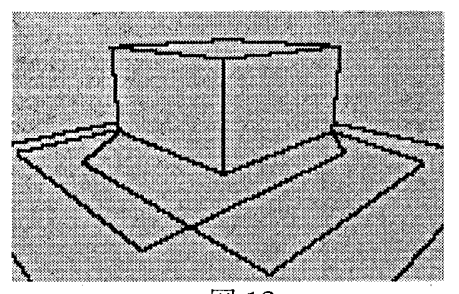

図 12
しかし、物体のエッジの明瞭性に比べて影のエッジはあいまいであ るので、物体のエッジほどの厳密な処理をほどこす必要はない。エ ッジの明瞭度に見合った計算精度を使い分けるという意味で、妥当 な方法と言える。 


\section{4 反射像のエッジのアンティエィリアシング}

鏡面での反射像のエッジもエイリアシング発生要素であり、反射 像についても新たなアンティエイリアシング処理のアルゴリズムが 必要である。

本研究のアルゴリズムでは、スキャンライン法の情報を計算高速 化に利用しているが、スキャンライン法は鏡面での映り込みが扱え ないので、反射像のエッジのアンティエイリアシングの高速化には 利用できない。そこで、「鏡面については、反射像のエッジ部分を抽 出せず、すべてスーパーサンプリングする」ようにする。その結果 を図 13 に示す。

図 13 を $640 \times 400$ ピクセル（サブピクセル $4 \times 4$ ）のサイズで計 算すると、均等スーパーサンプリング法では 61 秒注 2$)$ であったが、 新アルゴリズムでは 29 秒 ${ }^{2}$ 2) で、2.1 倍の高速化であった。両手 法で画質の違いはない。

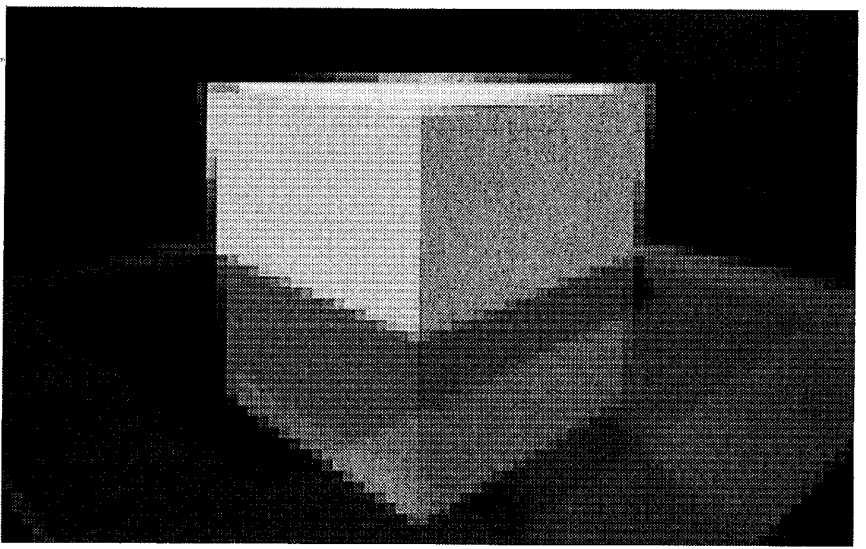

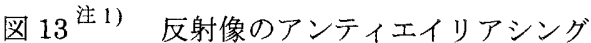

このアルゴリズムは、画像における鏡面部分の面積が少ない場合 に流速化に寄与するが、鏡面部分が多くを占める画像ではあまり 高速化が期待できない限界がある。そこで、広い鏡面領域を含む画 像を高速化したい場合には、画質を犠牲にすることになるが、「鏡面 ではすべてスーパーサンプリングせず、隣接する四つのピクセルの 鏡面反射成分を平均化してアンティエイリアシングする」方法も選 択肢に加える事ができる。この方法は、反射のエッジ部分の画質を 低下させるが、影や模様といった他の成分の画質には悪影響を及ぼ さない。

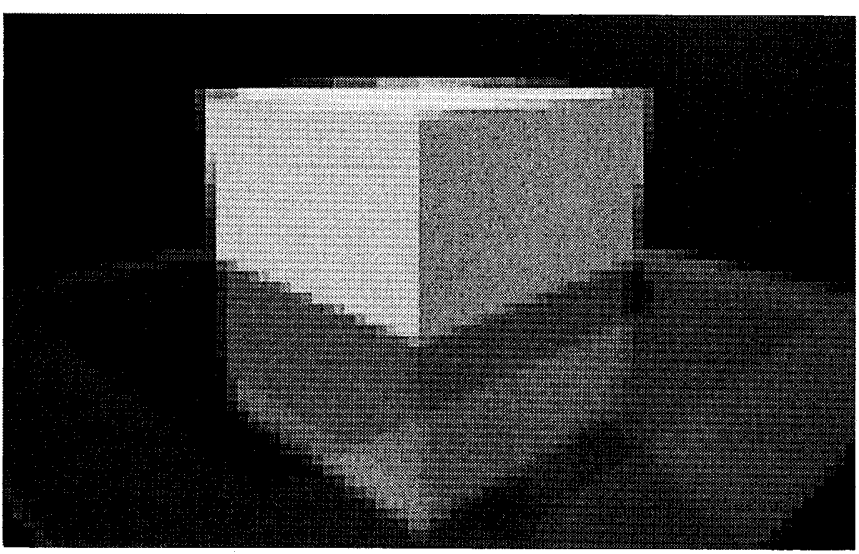

図 14 注 1) スーパーサンプリングなしの反射像
図 14 にこの方法で作成した画像を示す。図 14 を $640 \times 400$ ピク セル(サブピクセル $4 \times 4$ )のサイズで計算した計算時間は 7 秒 注 2) であった。図 13 と比べて、反射像のエッジ部分が若干ぼやけたよ うに表示されているが、計算時間は大幅に改善している。

\section{5 材贫の模滕のアンティエイリアシング}

物体表面にマッピングされる材質の模様もエイリアシングの原因 となる。図 2 の不正な縞模様は、マッピングの模様から生じるエイ リアシングの例である。ここまでの手法は、材質の模様については 関知しておらず、材質の模様のために新たなアンティエイリアシン グアルゴリズムが必要となる。

材質の模様のアンティエイリアシング手法については、MIP マッ

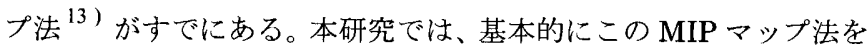
採用し、それに改良を加えて処理する方法を考案した。MIP マップ 法は既往の手法であるので、ここでの詳しい説明は省略し、注 5)に 概略のみを記している。

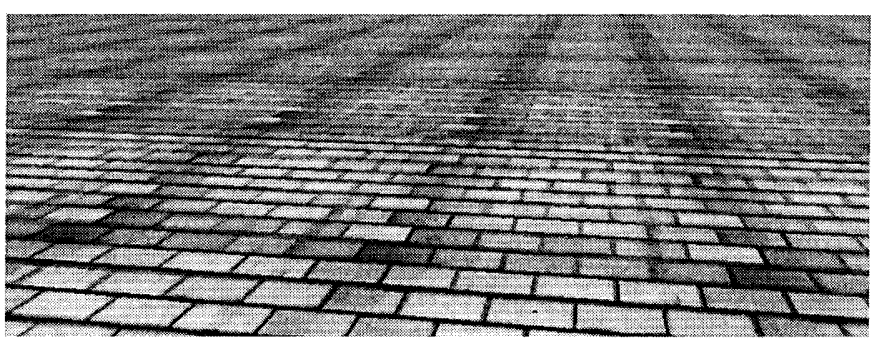

困 15 MIPマップ法の適用

図 15 は、図 2 の画像を既往の MIP マップ法で表現した画像であ る。遠方での縞模様が無くなり、画質が大幅に改善されている。た だ、MIP マップ法は、注 5)で示すように、遠方で画像精度を落と してエイリアシングを消去するアルゴリズムであるので、画像がぼ やけた表現になるのが否めない。そこで、本研究では、MIPマップ 法にスーパーサンプリング法を組み合わせて、ぼやけを改善する方 法を考案した。

マッピングは計算負荷の軽い処理であり、高速化しても全体の計 算時間に大きな影響がない。そこで新アルゴリズムでは、「マッピン グ処理に関してはエッジを抽出せず、マッピングされるすべてのピ クセルでスーパーサンプリングを行う」。ここで言うスーパーサンプ リングはマッピング処理のみのスーパーサンプリングである点に高 速化のアイデアがある。図 5 を見て分かるように、通常のスーパー サンプリングは「色計算」ルーチン全体をスーパーサンプリングす るが、ここでは、「色計算」ルーチンの中の「模様のマッピング」部 分だけをスーパーサンプリングし、残りの部分はスーパーサンプリ ングしない。「色計算」ルーチンで計算負荷がかかるのは、交点計算 や影計算などの残りの部分であるため、この部分をはじく事によっ て、すべてのピクセルにスーパーサンプリングしても高速化が実現 する。

このアルゴリズムで問題となるのは、物体処理（4.2 節）ではス ーパーサンプリングしないがマッピング処理ではスーパーサンプリ ングする、という状況が発生することである。マッピングするため にはあらかじめ物体処理でマッピングする場所の座標值を求めてお 
く必要があり、この状況は、マッピングする時にその配置位置が分 からないことを意味する。

この問題を解消するために、4.2 節で活用したスキャンライン法

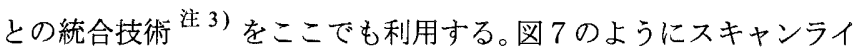
ン法です心゙てのサブピクセルでの可視物体の面番号が計算されてい るので、この面番号情報からその場所の座標值を逆算する（サブピ クセルでの面番号情報を使ってその面の平面方程式を取り出し、そ の平面と、サブピクセルの位置と視点を結んだ直線との交点を求め る)。通常の C G 処理の流れでは、3 次元空間から 2 次元の画面一座 標変換（投影）を抗こなうが、ここでは、逆に、画面（2次元）か ら空間 ( 3 次元) に座慓変換し、元の座慓值を推定する。

図 16 がこのアルゴリズムで作成した画像である。図 15 と比較し て、遠方の模様がより詳細に表現されている。図 $16(1024 \times 384$ ピクセル、 $4 \times 4$ サブピクセル) の計算時間は、均等スーパーサンプ リング法では 50 秒 注 2$)^{2}$ であったのに対し、本アルゴリズムでは同 じ画質で 7 秒注 2) で、7.1倍の高速化であった。

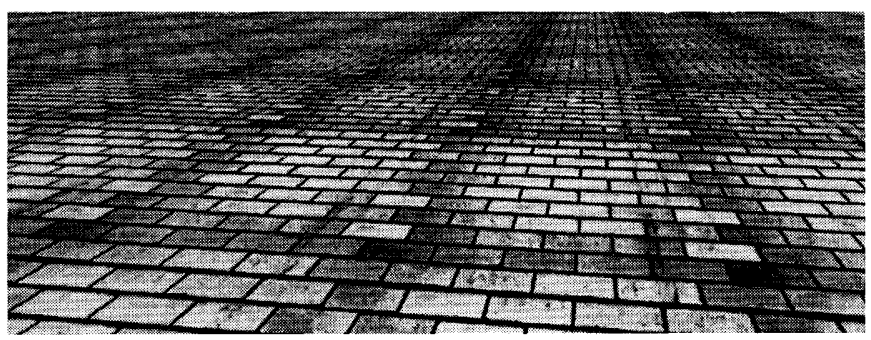

図 16 MIP マップ法とスーパーサンプリングの合成

\section{6 新アルゴリスムの処理の流れ}

図 17 に新アルゴリズム全体の流れ図を示す。図 5 と比較して分 かるように、図 17 の(a)，(b)，(h)の部分が、既往のスーパーサンプリ ング法から改良した新アルゴリズムの部分である。

下段の「色計算」ルーチンを使って、はじめにピクセル中央点で の色を計算する $(\mathrm{a})$ 。次にこのピクセルがスーパーサンプリングが必

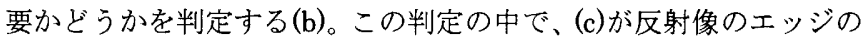
ための処理 (4.4 節)、(d)が物体のエッジのための処理 (4.2 節)、(e) が影のエッジのための処理（4.3 節）である。スーパーサンプリン グが必要ないと判定された場合(f)は、(a)で求めた色をピクセルの色 として使う。必要と判定された場合にのみ、スーパーサンプリング を行う $(\mathrm{g})$ 。

材質の模様については、(h)でスーパーサンプリングする。(h)で 処理することによって、(a)の時点で模様についてはスーパーサンプ リングされるので、(f)でスーパーサンプリングが省略された場合で も、模様についてはスーパーサンブリングされる（4.5 節）。

(e)の影重複回数の回数の判定は、(a)の時点で(i)の処理の時に影の 重複回数を保存することによって可能となる。そのために、(a)の処 理を(b)の前で行っている。

\section{5. 新アルゴリスムの高速化の効果}

新アルゴリズムの高速化の効果は、画像の複雑さに大きく影響さ れる。画像の複雑さによってスーパーサンプリングされる領域が変 化するからで、エッジの少ない単純な画像ほど高速化の効果が高く

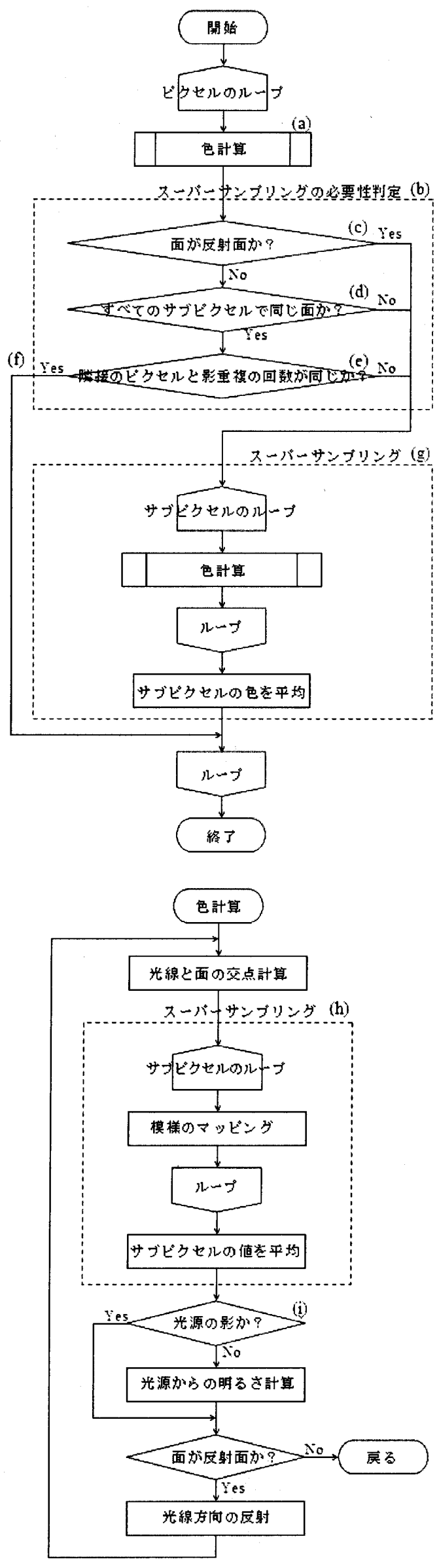

図 17 新アルゴリズムの処理の流れ 


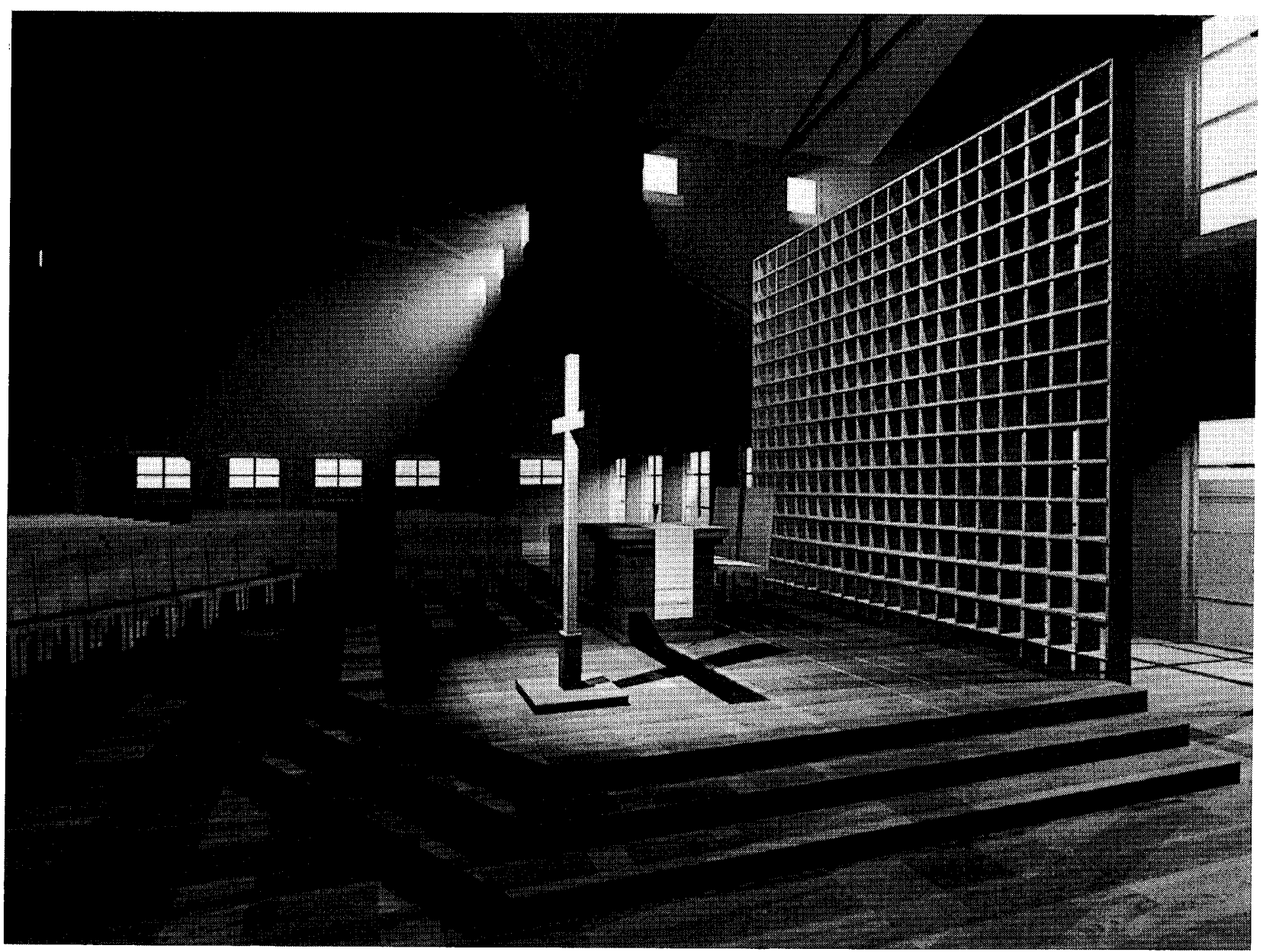

図 18 アンティエイリアシング高速化アルゴリズムの適用例

なる。そこで高速化の効果を評価するには、実際に建築分野で制作 されるようなモデルで計算時間を実測するのが妥当であるう。計算 時間測定に使用した画像は図 18 で、このデルは 28,000 の面と 22 の光源で構成され、ほぼすべての物体の表面に模様がマッピングさ れている。画像サイズは $1024 \times 768$ ピクセルで、サブピクセル数は 1 ピクセルあたり $16(4 \times 4)$ を採用している。

この画像作成に要した計算時間は、均等スーパーサンプリング法 では 17 分 30 秒注 2) であったのに対し、新アルゴリズムを適用す ると 4 分 31 秒注 2) で、3.9 倍の高速化であった。作成された画像 の画質は両手法で同等であり、高速化による画質劣化は無い。

新アルゴリズムは、作成する画像のサイズが大きくなるほど、高 速化の効果が高くなる特徴がある。図 18 の画像サイズを変更して、 均等スーパーサンプリング法（既往アルゴリズム）と新アルゴリズ

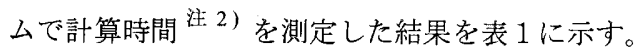

大きな画像ほど新アルゴリズムが高速化に有利なのは、画像が大

表 1 画像サイズによる高速化率の変化

\begin{tabular}{|c|r|r|c|}
\hline 画像サイズ(ビクセメ & 既往アルゴリズム & 新アルゴリズム & 高速化率 \\
\hline $256 \times 192$ & 1 分 6 秒 & 34 秒 & 1.9 \\
\hline $512 \times 384$ & 4 分 23 秒 & 1 分 39 秒 & 2.7 \\
\hline $1024 \times 768$ & 17 分 30 秒 & 4 分 31 秒 & 3.9 \\
\hline $2048 \times 1536$ & 69 分 52 秒 & 12 分 21 秒 & 5.7 \\
\hline
\end{tabular}

きくなるほど、エッジが属するピクセルの割合が小さくなり、その 結果スーパーサンプリングする領域が少なくなるからである。図 19 にその様子を示す。左図では、エッジ上にあるピクセル（スーパー サンプリングするピクセル：灰色）が全ピクセルの 4/9 (44\%)であ るのに対して、画像サイズを大きくした（ピクセルを細かくした） 右図では、8/36 (22\%)に減少している。
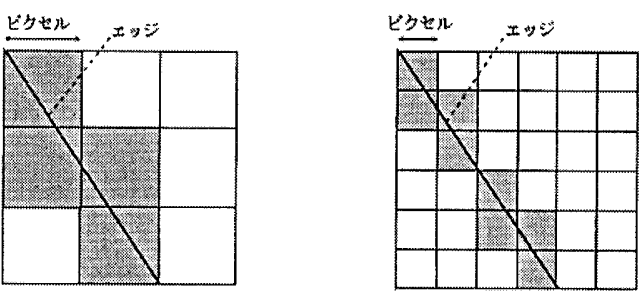

図 19 画像サイズによるスーパーサンプリング領域の変化

\section{6. まとめ}

建築分野の CG 制作にとって、エイリアシング現象は画像を劣化 させる重大な問題であり避けて通れないが、これを解消するには大 きな計算時間を要するのがネックとなってきた。本研究では、高画 質を維持したまま高速にエイリアシングを処理する新アルゴリズム を考案し、CG 制作効率を向上させることに成功した。

新アルゴリズムのアイデアは、物体、影、模様、反射といった表 現要素ごとにエイリアシングの発生箇所を抽出し、必要部分にのみ 
アンティエイリアシング処理を行う、という点にある。既往の方法 は、表現要素に関知せず一律にアンティエイリアシング処理してお り、これに比べて新アルゴリズムは、処理は複雑になるが、大きな 高速化が実現する。

\section{的辞}

本稿執筆にあたり、関東学院大学工学部の山崎均教授から貴重な指 摘とご指導を頂いた。ここに記して感謝の意を表します。

\section{注躯}

注 1）エイリアシングの違いを分かり易くするために、小さな画像を搪大し、 エッジを強調して表示している。

注 2）計算時間は CPU $1.7 \mathrm{GHz}$ Petium4 マシンによる測定值である。

注 3) CG 制作の主な手法として、スキャンライン法 ${ }^{27)}$ とレイトレーシング 法 ${ }^{28)}$ の二つがある。レイトレーシング法は、各ピクセルごとに物体 との交点計算を処理するのに対して、スキャンライン法は、ピクセルの 横方向の集まりであるライン単位で物体との交点計算を一括処理する ので、スキャンライン法の方が高速である。一方、反射や影などの表現 に関してはレイトレーシング法が勝っている。従って、スキャンライン 法でも可能な処理はスキャンライン法を使い、レイトレーシング法でし か表現できない部分にのみレイトレーシングを使うことによって、高度 な表現力を維持しながら、大幅な高速化が実兒できる。これがスキャン ラインとレイトレーシングの統合技術である。

注 4）サブピクセルのサンプル点が規則的に配置されていれば、スキャンライ ン法が使えるが、確率的サンプリング法ではサンプル点が直線上に並 んでいないのでスキャンライン法が使えず、すべてレイトレーシング 法により計算しなければならない。

注 5) MIP マップ法 ${ }^{13)}$ は、図 20 のようにあらかじめマッピングする画像を 複数の精度で用意しておき、視点からの距離に応じて最適な精度の画 像をマッピングに使う手法である。つまり、視点から近いところには 高精度の画像を、遠いところに流い精度の画像をマッピングする。 この時、精度の異なる画像が切り替わる境界で不連続にならないよう に、両方の画像を混合して滑らかに切り替わる処理を行う。
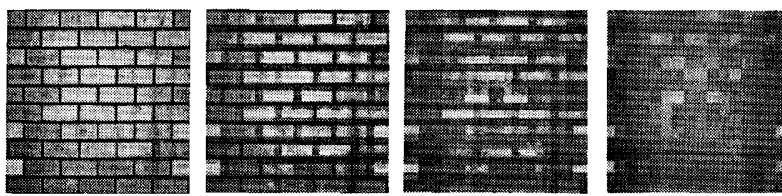

図 20 精度の異なるマッピング用画像の組

\section{参考文献}

1) Foley, J., Dam, A., Feiner, S. and Hughes, J., Computer Graphics Principles and Practice, second edition, 617-646, Addison-Wesley, 1990

2) http://www.siggraph.org/education/materials/HyperGraph/aliasing/ alias0.htm, 1993

3) Crow, F., The Aliasing Problem on Computer Generated Shaded Images, Communications of the ACM, vol.20, no.11, 799-805, November 1977

4) Catmull, E., A Hidden-surface Algorithm with Anti-aliasing, Computer Graphics, vol.12, no.3, 6-11, August 1978

5) Bloomenthal, J., Edge Inference with Applications to Antialiasing, Computer Graphics, vol.17, no.3, 157-162, July 1983

6) Carpenter, L., The A-buffer, an Antialiased Hidden Surface Method, Computer Graphics, vol.18, no.3, 103-108, July 1984

7）柴本, 荒岡，ポリゴン表示におけるエッジフィルタリング法，情報処理学 会論文誌, vol.29, No11, 1011-1018, Nov. 1988

8) Max, N., Cone-Spheres, Computer Graphics, vol.24, no.4, 59-62, August 1990

9) McCool, M., Analytic Antialiasing with Prism Splines, Computer Graphics, vol.29, no.3, 429-436, August 1995

10) Guenter, B. and Tumblin, J., Quadrature Prefiltering for High Quality Antialiasing, ACM Transactions on Graphics, vol.15, no.4, 332-353, October 1996
11) Feibush, E., Levoy, M. and Cook, R., Synthetic Texturing using Digital Filtering, Computer Graphics, vol.14, no.3, 294-301, July 1980

12) Norton, A., Rockwood, A. and Skolmoski, P., Clamping: a Method of Antialiasing Textured Surfaces by Bandwidth Limiting in Object Space, Computer Graphics, vol.16, no.3., 1-8, July 1982

13) Williams, L., Pyramidal Parametrics, Computer Graphics, vol.17, no.3, 1-11, July 1983

14) Cant, R. and Shrubsole, P., Texture Potential MIP Mapping, a New High-quality Texture Antialiasing Algorithm, ACM Transactions on Graphics, vol.19, no.3, 164-184, July 2000

15) Crow, F.C., A comparison of antialiasing techniques, IEEE CG\& A, vol.1, no.1, 40-48, Jan. 1981

16) Cook, R., Porter, T. and Carpenter, L., Distributed ray tracing, Computer Graphics; vol.18, no.3, 137-145, July 1984

17) Dippe, M. and Wold, E., Antialiasing through Stochastic Sampling, Computer Graphics, vol.19, no.3, 69-78, July 1985

18) Cook, R., Stochastic sampling in computer graphics, ACM Transactions of Graphics, vol.5, no.1, 51-72, January 1986

19) Mitchell, D., Generating Antialiased Images at Low Sampling Densities, Computer Graphics, vol.21, no.4, 65-72, July 1987

20) Painter, J and Sloan, K., Antialiased Ray Tracing by Adaptive Progressive Refinement, Computer Graphics, vol.23. no.3, 281-288, July 1989

21) Kirk., D. and Arvo, J., Unbiased Sampling Techniques for Image Synthesis, Computer Graphics, vol.25, no.4, 153-156, July 1991

22) Mitchell, D., Spectrally Optimal Sampling for Distribution Ray Tracing, Computer Graphics, vol.25, no.4, 157-164, July 1991

23) Haeberli, P. and Akely, K., The Accumulation Buffer: Hardware Support for High-Quality Rendering, Computer Graphics, vol.24, no.4, 309-318, August 1990

24) Schilling, A., A New Simple and Efficient Antialiasing with Subpixel Masks, Computer Graphics, vol.25, no.4, 133-141, July 1991

25) Molnar, S., Eyles, J, and Poulton, J., PixelFlow: High_Speed Rendering Using Image Composition, Computer Graphics, vol.26, no.2, 231-240, July 1992

26) http://www.nvidia.com/object/feature intellisample.html

27) Watkins, G.S., A Real Time Visible Surface Algorithm, Ph.D. Thesis, UTEC-CSc-70-101, NTIS AD-762 004, Computer Science Department, University of Utah, Salt Lake City, UT, June 1970

28) Whitted, T., "An improved illumination model for shaded display," Communication of the ACM, 23(6), 343-349, June 1980

(2005年 1 月 21 日原稿受理, 2005 年 7 月 19 日採用決定 